\title{
DEATH, NATIONAL MEMORY A D THE SOCIAL CONSTRUCTION OF HEROISM
}

\author{
BY WALE ADEBANWI* \\ University of Cambridge
}

\begin{abstract}
Ancestors occupy a central place in African cosmologies and social practices. The death and the remembrance of Lt-Col. Adekunle Fajuyi, the Military Governor of Western Nigeria who was killed during a military coup in I966, is used in this essay to critique the assumptions in the literature about ancestors, by linking the recent dead with the long dead in a lineage of ancestral practices. I focus on the ways in which Fajuyi's death was used in constructing ethno-national memory and history in the context of 2 ist-century challenges faced by the Yoruba in national politics, particularly in relation to unequal ethnoregional relations. Here, I attempt to historicize commemoration as a ritual of ethno-national validation.
\end{abstract}

KEY WORDS: West Africa, Nigeria, memory, political culture, identity.

\section{NTRODUCTION}

In May I999, Nigeria finally returned to democratic governance after I 6 years of military rule. The new atmosphere of freedom and democratic politics created the space for the public expression of all forms of political, cultural and social solidarities hitherto discouraged, or even criminalized, under the military. Given the nature of ethno-regional rivalries and competition, particularly among the three major ethno-regional blocs in Nigeria - that is, Hausa-Fulani in the north, Igbo in the east and Yoruba in the west - histories and memories played key roles in the attempt to reconstitute the Nigerian state and re-negotiate the basis of national solidarity at the end of the crises provoked by the martial dictators. This was particularly so in the context of the struggle for power among the political elites of the three major ethno-regional groups and those of the hundreds of minority groups.

A demonstration of these struggles for the re-negotiation of the basis of national solidarity from the Yoruba standpoint was the deification of Lieutenant-Colonel Adekunle Fajuyi, the Military Governor of the Western Region, who was assassinated in a counter-coup led by northern soldiers in July i 966. The master narratives of the 'virtues of sacrifice, loyalty, honour

* Wale Adebanwi is a Bill and Melinda Gates Scholar at Trinity Hall, University of Cambridge. This essay is part of a more elaborate study of the significance of death in Nigeria. Financial support for fieldwork was provided by the Bill and Melinda Gates Cambridge Trust, the Department of Social Anthropology, Cambridge, and Trinity Hall, Cambridge. I thank Megan Vaughan and Stephen Ellis for inviting me to participate in the conference on 'Death in Africa'. 
and courage that Fajuyi exemplified in choosing death instead of life', ${ }^{1}$ were re-appropriated by the dominant Yoruba power elite organized around Afenifere, ${ }^{2}$ a sociocultural and political group, and used in re-negotiating national memory in the service of present and future political interests and gains. Between 2000 and 2003 , elaborate plans were made to celebrate the memories of 'Yoruba heroes', including the late Chief Obafemi Awolowo, popularly recognized as the greatest Yoruba, second only to the progenitor, Oduduwa; late Chief Moshood Abiola, who is presumed to have won the presidential elections in I993, which were annulled by the military-the annulment provoked a national crisis which eventually led to Abiola's incarceration and death; and Lt-Col. Adekunle Fajuyi. In this essay, I focus on the ways in which Fajuyi's death was used in constructing ethno-national memory and history in the context of 2 ist-century challenges that were faced by the Yoruba in national politics, particularly in relation to unequal ethnoregional relations. Here, I attempt to historicize commemoration as a ritual of ethno-national validation.

There is an assumption in the literature that modernization leads to the emancipation of the living from the control of the dead. ${ }^{3}$ In this context, ancestor worship is assumed to be part of the worldview of 'traditional', 'past-oriented', indeed 'backward' societies, a practice in which 'modern', 'future-oriented' and 'progressive' societies will not be involved. ${ }^{4}$ Despite this assumption, contemporary, modern societies continue to be enchanted by the dead in different ways. From the massive reburials, and the destruction and removal of the statues of Marx, Lenin, and Stalin, in the postCommunist Eastern Europe ${ }^{5}$ to the battles over burial rites and burial places in Africa, ${ }^{6}$ from the 'secular' worship of Atatürk in Turkey ${ }^{7}$ to the continued agency of a recent Yoruba ancestor, Obafemi Awolowo, in Nigeria, the dead continue to animate the study of power, politics and social relations. ${ }^{8}$ This is due to the fact that 'human activity nearly always has effective and meaningful dimensions and takes place through complex symbolic processes'. 9 Where death is considered as the 'indicator and invigorator of political life', ${ }^{10}$

1 Segun Gbadegesin, 'Foreword', in Akinyemi Onigbinde (ed.), The Road to Lalupon: Tribute to Gallantry (Ibadan, 200I), xvi.

2 'Afenifere', even though formally (re-)started as the name of an organization in the I 990s, was adopted as the Yoruba name for the political party Action Group (AG), in I 950 os and I960s Nigeria, specifically because the then largely illiterate population could relate better to that name than to the actual name of the party.

3 Michael C. Kearl and Anoel Rinaldi, 'The political uses of the dead as symbol in contemporary civil religion', Social Forces, 6 I (I983), 693-708. $\quad 4$ Ibid.649.

5 Katherine Verdery, The Political Life of Dead Bodies: Reburial and Postsocialist Change (New York, i 999).

6 David William Cohen and E. S. Atieno Odhiambo, Burying SM: The Politics of Knowledge and the Sociology of Power in Africa (London, I992); Patricia Stamp, 'Burying Otieno: the politics of gender and ethnicity in Kenya', Signs, i6 (I99 I), 808-54; Isaac K. Nyamongo, 'Burying the dead, culture and economics: an assessment of two Kenyan cases', Open Forum ( I 999), 255-6 I.

7 Yeal Navaro-Yashin, Faces of the State: Secularism and Public Life in Turkey (Princeton, 2002). $\quad{ }^{8}$ Verdery, The Political Life, 22.

10 Kearl and Rinaldi, 'The political uses of the dead', 694. 
politics, in a sense, can be viewed as 'a realm of continual struggles over meaning, or signification'. 11

In the social sciences and humanities, despite the centrality of death to the understanding of social life, death and the dead are only recently attracting the kind of academic attention that they deserve. Anthropology seems to be the only major exception to this, given the pre-occupation of the discipline, from its earliest beginnings, with an attempt to understand death, its social construction and its impacts on the constitution of, largely, 'primitive' society. For instance, Emile Durkheim's attempt at understanding the social factors shaping the religious thought system was, in part, a reaction against the reductionist accounts of Tylor and others who saw death as the source of religion, and therefore of society. ${ }^{12}$ On the contrary, in political science, the use of death as a powerful symbol of social mobilization is yet to be fully appreciated and is therefore under-theorized. Despite this, however, across time and cultures, death remains an essential part of social life, as it reveals 'the most fundamental sociocultural structures and dynamics' ${ }^{13}$ Following the Durkheimian and Radcliffe-Brownian traditions, this essay shows a specific context in which social rituals involving the dead contribute, in particular ways, to the collective integrity and solidarity of the groups that use them. ${ }^{14}$

The death and remembrance of Lt-Col. Adekunle Fajuyi is used to critique not only the assumed characteristic inactivity of ancestors, but also the assumption in the literature that the idealization of ancestors is independent of their lifetime careers. I do this by explicating the ways in which the newly dead are linked with the long-dead in a lineage of ancestral practices. Through the examination of the sociocultural essence and political value of death, I argue that Fajuyi enters into ancestorhood through the commemoration and celebration of his death and the narratives of his sacrifice and heroism which ritualize ethno-national solidarity, collective destiny and unity. What does (Fajuyi's) death mean in the Yoruba context? What do such dead signify within a collective political project? Why was this commemoration of Fajuyi's assassination important 35 years after his death? I attempt to understand how the narratives of past, present and future are read into a singular act of 'sacrifice' in a process in which a 'sacrificial lamb', Fajuyi, is converted into a current or recent ancestor and also united with the earlier ancestors in the political struggles of his Yoruba ethnicnationality. Also, I examine the ways in which the Yoruba (Afenifere) slant on a particular history is privileged in the service of the group's interests. Writing histories, particularly in the context of commemoration, involves reconstructions of the past in the service of group glory and solidarity.

This essay relies primarily on the volume published in commemoration of Fajuyi's death, The Road to Lalupon: Tribute to Gallantry. ${ }^{15}$ The collection of essays, which was sponsored by Afenifere, is announced not only as 'a repository of history and politics' but also as 'a study in the deep cultural ethos of a proud race'. ${ }^{16}$ This is complemented by newspaper reports of the assassination of Fajuyi and the commemoration of his death in $200 \mathrm{I}$, and

11 Verdery, The Political Life, 24.

${ }^{12}$ Kearl and Rinaldi, 'The political uses of the dead', 694.

${ }^{14}$ Ibid. 695. $\quad{ }^{15}$ Onigbinde (ed.), The Road to Lalupon.

${ }^{13}$ Ibid.

${ }^{16}$ Ibid. 
participant-observation while the author was on fieldwork in Nigeria between 2004 and 2007.

THE ROUTE OF DEATH

The stage for the events that canonized Lt-Col. Fajuyi was set long before Nigeria gained independence from British colonial rule in October I960. Many of the disparate ethnic groups that were to be forced into the British colonial enterprise had had no form of contact among themselves before the arrival of the European colonialists. However, a few of the groups had related through either trade or religion, or even through conflict and war. The most significant example of the last two was in much of what became Northern Nigeria, where the migrant Fulani waged a jihad in the nineteenth century against their Hausa hosts and many other minority groups, and subsequently imposed Fulani (Islamic) rule in the affected areas.

Fulani rule from the nineteenth century on was established under the Sokoto Caliphate with the Sultan of Sokoto as the principal head of the new Islamic state. However, there were a few minority ethnic groups in the north which were unaffected by the jihad and remained relatively independent of the new Islamic state. In the south of Nigeria, apart from the two major ethnic groups, the Yoruba and the Igbo-both of which were yet to forge any strong internal ethnic solidarity at this time - there were also several minority groups, which were all forced into the colonial state of Southern Protectorate. In I9I4, principally on the advice of the former Colonial Governor of the Northern Protectorate, Lord Frederick Lugard, the two protectorates were amalgamated into a single protectorate called Nigeria, under the headship of a single Governor-General, Lugard.

The resultant tension and rivalries between the three major ethnic groups in Nigeria were to define much of the late r 940 s and I95os in the process of negotiating Nigeria's independence. The north, in land space and in disputed population figures, was much bigger than the south. It was organized around the Northern People's Congress (NPC), led by Sir Ahmadu Bello, the Sarduana of Sokoto and a prince of the powerful Sokoto Caliphate, who later became the Premier of the Northern Region during the process of limited self-rule. The west was organized around the Action Group (AG), led by Chief Obafemi Awolowo, who also eventually became the Premier of the Western Region. What was initially a national political party, the National Congress of Nigerian Citizens (NCNC), led by Dr. Nnamdi Azikiwe, was forced by circumstances to be regarded as a party of the Eastern Region, where it formed a government under the premiership of Azikiwe.

The NPC, as the senior partner, and the NCNC, as the junior partner, entered into an alliance which subsequently formed the federal government under a parliamentary system at independence in i960. Thus, the NPC's Sir Abubakar Tafawa Balewa became the Prime Minister while the NCNC's Dr. Azikiwe became the ceremonial President. The AG became the official opposition party at the federal level, with Awolowo as the leader of opposition in the federal parliament. A crisis broke out in the AG in 1962 during which the Premier of the Western Region, Chief Samuel Ladoke Akintola, Awolowo's successor-alongside a few others-was expelled from the party for entering into a political understanding with northern politicians, 
particularly the Premier of the Northern Region, Ahmadu Bello, among other allegations. Akintola then formed another party with his supporters, which was later named the Nigerian National Democratic Party (NNDP). The NNDP entered into an alliance with the NPC upon the collapse of the NPC-NCNC alliance. Widespread violence marked the rift in the ranks of the $\mathrm{AG}$ as attempts were made to remove Akintola from office by the AG-dominated regional parliament. Akintola's allies in the ruling NPC government then declared a state of emergency in the Western Region and accused Awolowo and his close supporters of planning to overthrow the federal government by force of arms. They were later tried and convicted in I 963 .

Akintola was returned to office in disputed elections which were again marred by widespread violence in the Western Region. In the context of all this, some young soldiers, who were mostly of Igbo extraction, struck on I 5 January i 966 . In what was later described as a 'mutiny', they killed political leaders and military chiefs in Lagos, Ibadan and Kaduna. Those killed included the Prime Minister, Tafawa Balewa; the Premiers of the Northern and Western Regions, Ahmadu Bello and the man regarded as Bello's lackey in the west, Ladoke Akintola; the Federal Minister of Finance, Festus Okotie-Eboh; and ranking soldiers, including Brigadier Z. Maimalari, Brigadier S. A. Ademulegun (and his wife), Cols. R. A. Shodeinde and Kur Mohammed, Lt-Cols. J. Y. Pam, A. C. Unegbe and A. Largema.

However, a few of the coup plotters of Igbo extraction who were expected to arrest and kill, upon resistance, the Igbo Premier of the Eastern Region, Michael Okpara, and the Premier of the Mid-West Region, Dennis Osadebey, put the former under house arrest and failed even to reach the latter. This provoked the description of the coup as a 'tribal uprising'. ${ }^{17}$ This allegation, as one of the plotters, Adewale Ademoyega states, ignored the fact that not only did some northern officers and men take part in, and approve of, the coup, but also they were 'extremely jubilant and most vociferous that the revolution should continue'. ${ }^{18}$

The mutiny, although hailed in most quarters as a God-send, was eventually halted by the senior cadre of the military which took over the reins of power and detained the majors who executed the coup. The head of the Nigerian Army, Major General J. T. U. Aguiyi Ironsi, an Igbo, then took over power as the head of the new military government. After establishing himself securely in office, Ironsi stated that disunity was the major crisis faced by the recently independent country. Owing to this, he announced plans to abrogate the federal system in favour of a unitary system in which the civil service was to be unified and the regions were more or less to cease to be the semi-independent parts of a federating unit. On 24 May r 966 , despite opposition in the Western and Northern Regions, Ironsi promulgated Decree No. 34, I966, which abrogated federalism and turned the regions into 'groups of provinces'. According to Ironsi, the new decree intended to 'remove the last vestiges of intense regionalism of the recent past, and ... produce that cohesion in the government structure which is so

${ }^{17}$ James J. Oluleye, Military Leadership in Nigeria, I966-I979 (Ibadan, I985).

18 Adewale Ademoyega, Why We Struck: The Story of the First Nigerian Coup (Ibadan, I98I), го8. 
necessary in achieving and maintaining the paramount objectives of the National Military Government ... national unity'. ${ }^{19}$

This decision resonated with a long-drawn-out struggle between federalists (derided as 'Pakistanists') and unitarists in Nigeria. The Igbo, led by Azikiwe, given their mobility and establishment of businesses across the country, among other reasons, had favoured a unitary system for Nigeria before independence in I960. In this era, there were accusations, in the Yoruba west and also in the Hausa-Fulani north, of plans to foist 'Igbo domination' on the rest of Nigeria. Azikiwe was persuaded in the r 950 s to support federalism. Therefore, the imposition of a unitary system of government under an Igbo head of state was seen in the west and the north as a return to this debate and the victory of the (Igbo) unitarists over the (Yoruba and northern) federalists. Against the backdrop of the loss of the crème of its political leadership, the north, which was then in deep fear of 'domination' by the more educated and more developed south, was dissatisfied with the proposed structural changes. It was feared in the north that southern, particularly Igbo, administrators would be sent to the north to govern the people.

Beyond this, there were already muted discussions of 'Igbo domination' in the north as a consequence of the narratives of the 'Igbo coup' of January I 966. This concern was fed by the fact that the President (an Igbo), and the Premiers of the Eastern and Mid-Western Regions (also Igbo, unlike the Premiers of the North and West), and ranking Igbo soldiers were not killed during the coup. Apart from allegedly promoting Igbo officers over and above some of their non-Igbo contemporaries and even superiors, the regime of Ironsi was also accused of being run mostly by Igbo technocrats and politicians. ${ }^{20}$ For example, the Igbo who were already predominant in the upper hierarchy of the Army (6o per cent in January I 966) became even more predominant three months after Ironsi took over (73 per cent). ${ }^{21}$ Another touchy point was the alleged refusal of Ironsi to prosecute the officers, mostly Igbo, who led the coup - or 'mutiny' - of January i 966 . For northern officers and politicians, this amounted to 'an inaction against an illegal action' and 'condoning indiscipline or treason' ${ }^{22}$

However, despite the opposition, the military government went ahead with the structural changes and imposed a unitary government on the troubled nation. Three days after the announcement of the decree, widespread violence broke out in the north in which people of eastern origin, particularly the Igbo, were killed by mobs. Ironsi then decided to tour the whole country to explain the new changes to the leaders of its different sections.

On the night of 28 July, while in Ibadan, the capital of the Western Group of Provinces, to meet with traditional rulers from all over the country, Lt-Col. Fajuyi held a state dinner in honour of General Ironsi, during which northern soldiers passed the code word 'Araba' ('separation') among

19 Quoted in Isawa J. Elaigwu, Gowon: The Biography of a Soldier-Statesman (Ibadan, I 986), 5 I-2.

20 See Ademoyega, Why We Struck, I го-ı I ; Oluleye, Military Leadership in Nigeria, 32-3; Elaigwu, Gowon, 52-4.

21 Ademoyega, Why We Struck, I I I .

22 Elaigwu, Gowon, 6 I. 
themselves. That night, fighting broke out in Abeokuta garrison where the Igbo commander and many Igbo soldiers were killed. In Ibadan, there was a burst of gun-fire when a gun was being loaded, which was mistaken by northern soldiers as the signal to put their plan into operation. On the morning of 29 July, soldiers of northern extraction 'abducted' Ironsi and his host, the Military Governor of the Western Group of Provinces, Lt-Col. Adekunle Fajuyi, and later killed them at Lalupon, a sleepy rural community about 12 kilometres from Government House in Agodi, Ibadan. The leader of the detachment of the Nigerian Army that took care of General Ironsi's security, Lt. Walbe was, unknown to Ironsi, in contact with Major Theophilus Danjuma, a northern officer, who was always in Ironsi's entourage and was the one who coordinated the decision of the northern soldiers to remove Ironsi as head of state. ${ }^{23}$

It was later reported that, when the northern soldiers came to Government House, they only demanded to take Ironsi away. The dominant narrative has it that Fajuyi was asked to abandon Ironsi to his fate, but he refused to do so and chose rather to die with his guest and Supreme Commander. For instance, Sanmi Ajiki in his biographical work Francis Adekunle Fajuyi, recorded that Fajuyi told his guest, Ironsi:

I make bold to declare to you that ... I am with you soul, spirit and body. And mark my words - whatever happens to you today happens to me. I am your true friend, dear J. U. T. like the dove to the pigeon, and by the grace of our good God, so will I humbly yet proudly remain till the very end.

To this, Ironsi reportedly replied, 'Yes! Francis [Fajuyi], I retain my absolute confidence in you. I have never for once doubted your integrity' ${ }^{24}$

The abduction of Ironsi and Fajuyi was a prelude to a counter-coup executed by soldiers of northern extraction, some of whom even wanted the north to secede from the rest of Nigeria. As Isiwa Elaigwu argues, 'there is no doubt that the July [counter-]coup was not planned country-wide. [It was a] vengeful coup ... aimed at removing Ironsi and some of his suspected Ibo cohorts in the army'. ${ }^{25}$ After a few days' interval, a ranking northern soldier, Lt-Col. Yakubu Gowon, was declared the Head of State. It was not until January I967, almost six months later, and at the insistence of the Military Governor of the Eastern Region, Col. Odumegwu Ojukwu, during the Aburi Talks (in Ghana), that the new military regime formally announced that General Ironsi and Lt-Col. Fajuyi had been killed in the mutiny of 29 July I 966 .

The celebration of Fajuyi's 'sacrifice', after the deaths of both men were announced, could not have been elaborate, if it happened at all, since the announcement was made in the context of the nation's slide towards a civil war. Tension was already very high in the country and the Igbo and easterners in general were to suffer a pogrom in the north of Nigeria. The secessionist Republic of Biafra was declared in July r967. Despite this however, Fajuyi's sacrifice was celebrated in a few newspaper articles and in

23 Ibid. 64.

24 Sanmi Ajiki, Francis Adekunle Fajuyi: The Martyred Soldier (Saga of a Man of Peace Who Died by Violence) (Lagos, r 996) i6 г.

${ }^{25}$ Ibid. 64. 
a funeral service in the early months of 1967 , almost one year after he and Ironsi were assassinated. The Daily Times described him as 'a man whose proven boundless courage and spirit of sacrifice would forever be an inspiration to his generation and the generations to come' ${ }^{26}$ The Daily Sketch stated that 'all of us must remember that though [Fajuyi] died, yet he lives on as a fountain of honour to his [Yoruba] race', adding that in 'the ultimate verdict of history', the Yoruba 'must be able to find a greater tomorrow for our race, for ourselves and for our children'. ${ }^{27}$ The Nigerian Outlook based in the Igbo east mourned 'the loss to the nation of this brave soldier who preferred the path of honour - even unto death - to any form of shiftiness and subterfuge', adding that 'We in Eastern Nigeria have every reason to feel sore at the death of this singular character'. ${ }^{28}$ The Nigerian Tribune argued that 'no soldier could have died more gallantly and more honourably' than Fajuyi, affirming that 'Every Yorubaman, indeed, every Nigerian, ought to feel proud that one of us could willingly choose to pay the supreme sacrifice rather than betray a guest'. ${ }^{29}$ Lt-Col. Chukwuemeka Odumegwu Ojukwu, the then Military Governor of the Eastern Region, said that Fajuyi died 'a hero and martyr' whose 'admirable conduct was truly Nigerian and Christian'. Fajuyi's death was, for Ojukwu, in the service of the 'fight against disorder, confusion and national decay' ${ }^{30}$

However, the immediate backdrop to the commemoration of Fajuyi's death and sacrifice in the early years of the twenty-first century must be set out as it relates to 'history', enduring patterns and long-running master narratives of ethno-national persecution popular among the Yoruba. Also the commemoration reflects the way in which a person's sacrifice is used as a reminder 'of a nation's collective achievements and the accomplishments of putative ancestors with whom contemporary citizens are encouraged to identify'. ${ }^{31}$ When we think about 'history' in this context, we are, as Susan Crane has argued, 'thinking in terms of commemoration, or, in Mark Stand's 'poetic' words, the "gift" sent into the world so that the future might mourn'. ${ }^{2}$

\section{BECOMING A HERO:DEATH AS GIFT}

$\ldots$ it came in a language

Untouched by pity, in lines, lavish and dark,

Where death is reborn and sent into the world as a gift,

So the future, with no voice of its own, nor hope

Of ever becoming more than it will be, might mourn.

- Mark Strand, 'Orpheus Alone',33

${ }^{26}$ Daily Times, 28 January 1967.

${ }^{27}$ Daily Sketch, 28 January i 967. Emphasis added.

28 Nigerian Outlook, 28 January 1967.

${ }^{29}$ Nigerian Tribune, 28 January I 967. Emphasis added.

${ }^{30}$ Onigbinde (ed.), The Road to Lalupon, I39.

${ }^{31}$ Vera Zolberg, 'Contested remembrance: the Hiroshima exhibit controversy', Theory and Society, 24 (1998), 565-90.

${ }^{32}$ Susan Crane, 'Writing the individual back into collective memory', American Historical Review, I02 (I 997), I 372.

${ }^{33}$ In Nina Kossman, Gods and Mortals : Modern Poems on Classical Myths (New York, 200I), II 6 . 
The process of deliberate canonization of Lt-Col. Fajuyi, of 'submerging [his] suffering and loss to greater causes', more than three decades after his death, started as a public symposium in Ibadan on 23 June 2000, under the auspices of Yoruba Parapo - a pan-Yoruba cultural group. The symposium was held to honour three Yoruba heroes, Chief Obafemi Awolowo, Chief M. K. O. Abiola and Lt-Col. Francis Adekunle Fajuyi, within the framework of 'collectively shared assumptions about the indebtedness of the living to their heroic compatriots and ancestors'. ${ }^{34}$ At the symposium, Dr. Ogunlusi, who was Fajuyi's private doctor, lamented that Fajuyi had been forgotten by the Yoruba people and their leadership. Professor Bolaji Akinyemi, former Foreign Affairs Minister and ranking member of the Afenifere, the dominant Yoruba politico-cultural group, responded by promising that the group would take up the matter. ${ }^{35}$

At the next meeting of the group in the country home of its leader, Senator Abraham Adesanya, Akinyemi raised the matter of the "Yoruba neglect of its dead heroes, and the need to take remedial action'. Akinyemi reports that 'the reaction was overwhelmingly positive' with a committee set up under his chairmanship to make proposals. Ostensibly, the members of the Afenifere became mindful of the fact that the act of recognizing heroes is 'an exercise in national self-validation' as Ali Mazrui ${ }^{36}$ has argued. The Akinyemi Committee's proposal was for a comprehensive programme of honouring past, present and future heroes of the Yoruba nation with the establishment of a pantheon along Athenian lines. This proposal must be put in the context of the particular meaning of Yorubaness that was ascendant in that decade, that is, roughly between I99I and 200I, as this meaning was compared and contrasted with the narratives of 'injustices' perpetrated against the Yoruba by the rest of Nigeria over time. As Akinyemi explains it:

Perhaps even now, we still underestimate the sense of siege that the Yoruba nation has felt in the Nigerian state since 1962. The Yoruba nation is the only one to have been subjected to a state of emergency. Its leaders had been jailed. Its leaders have been assassinated. Its leaders have been murdered. Its people had been subjected to ethnic cleansing from every arm of the Federal services. In its struggle for just sheer survival, we got to propitiate the ancestral gods... The sacrifice made during $1993^{-1} 998$ created the mind-set among the Yoruba nation that was receptive to hero-worship. ${ }^{37}$

Such narratives of long-running persecution of the Yoruba starting from Awolowo's detention, trial and imprisonment between r962 and r966 and continuing up to Abiola's detention, trial and eventual death (or what many believe to be his 'assassination') between I 993 and I998, are key to understanding the meaning of Yorubaness in contemporary Nigeria as it is suffused with a strong rhetoric of heroic sacrifice by Yoruba leaders. Such sacrifices, whether they lead directly to death (in Fajuyi's and Abiola's cases)

${ }^{34}$ John Nelson, 'Social memory as ritual practice: commemorating spirits of the dead at Yasukuni Shinto shrine', Fournal of Asian Studies, 62 (2003), 443.

${ }^{35}$ Bolaji Akinyemi, 'The Afenifere connection', in Onigbinde (ed.), The Road to Lalupon, i 7 .

${ }^{36}$ Ali Mazrui, 'On heroes and uhuru worship', Transition, I I (Nov. I963), 23-8.

${ }^{37}$ Akinyemi, 'The Afenifere connection', I7-18. 
or not (in Awolowo's case) become materials for the eventual celebration or even deification of the personalities that made such sacrifices in life - and more so, in death. As is evident from the Fajuyi case, constant references are made to the other big Yoruba heroes, particularly Awolowo-who is the ultimate Hero (with a capital ' $H$ '), whose death and burial remain the most significant in Nigeria's history - and Abiola, whose death, some had feared, was capable of provoking a second civil war in Nigeria. It can therefore be argued that the Fajuyi memorial is set within contemporary ideas of Yorubaness as a beleaguered identity within Nigeria and as an identity that intrinsically carried some 'noble ideals'. As Lori J. Durcharme and Gary Alan Fine ${ }^{38}$ argue, by looking at a society's heroes and the mechanism through which they are commemorated and celebrated, we can uncover the values for which that society stands, given that 'the memory of heroic identities and events reveals the ideals upon which social solidarity rests. Celebration of a remembered past enhances commitment to those ideals' ${ }^{39}$

The recommendation of the Akinyemi Committee was debated at the Afenifere meeting and it was eventually decided that the proposed Athenian model could be a future project while the Fajuyi memorial should be taken up immediately. Another committee was therefore set up under Engineer Bayo Adenekan to plan 'the inaugural commemoration of Fajuyi's act of heroism'. ${ }^{40}$ For the Yoruba, there are interesting ironies or paradoxes in the Afenifere commemoration of Fajuyi's death. First, the Yoruba military class, to which Fajuyi belonged, had always been accused of refusing to enter into strategic alliance with the Yoruba (civil) political class, in ways that denied the Yoruba of the other crucial arm of their hegemonic project in the Gramscian sense: force or domination. This has always been contrasted with the Hausa-Fulani (northern) military class which had come to be seen as the military wing of the 'northern oligarchy' (the traditional and political elite). Indeed, an unconfirmed story has it that Awolowo was rebuffed by the members of the Yoruba military class when he approached them about the harmonization of their respective positions during the pre-civil war crisis. ${ }^{41}$

Also, despite the history of wars and violence in Yorubaland in the nineteenth century which fractured the Oyo Empire, and the tradition of omo ogun (war-boys), the modern military was viewed by the Yoruba, who have come to see themselves as 'modern', 'civil' and 'civilized', as the refuge for the ne'er-do-well or the preserve of vagabonds. Therefore, 'respectable' Yoruba families did not allow their wards to join the Nigerian Army. While there was a deliberate policy of recruitment into the Army by the leaders of the north, particularly into the infantry and armoured corps, many of the Yoruba who eventually joined the Army were mostly in the non-combatant sectors such as the engineering and other corps. Awolowo, unlike the leader of the north, Ahmadu Bello, is often accused of committing the 'strategic error' of not turning his mind to the possibility that the Nigerian military would eventually decide the fate of the country, despite his unconfirmed

38 Lori J. Durcharme and Gary Alan Fine, 'The construction of nonpersonhood and demonization: commemorating the traitorous reputation of Benedict Arnold', Social Forces, 73 (June I995), I 309.

40 Akinyemi, 'The Afenifere connection', i 8. ${ }^{39}$ Ibid.

41 Ibid. 
effort to harmonize the position of the two classes before the civil war. It is therefore interesting that the core Awolowo group, Afenifere, would celebrate the memory of a member of the Yoruba military class, which did not identify with the political class and which the political class were accused of failing to see as a strategic partner.

Again, Afenifere was often accused of being a cult that was concerned only with its own. ${ }^{42}$ Fajuyi, in this context, could not be regarded as 'one of their own'. Indeed, Akinyemi noted that there was no evidence that Fajuyi ever met Awolowo, the Yoruba avatar. Yet, it is significant for the group that Fajuyi was part of the military regime 'that got rid of the political enemies of Chief Awolowo and Afenifere' through the January i 966 coup. ${ }^{43}$ Akinyemi argues that "there is no doubt that both the Balewa Federal Government and the Akintola-controlled Western Region Government were determined to eliminate Afenifere politically'. ${ }^{44}$ Ironically, this military regime, which was said to have eliminated those who wanted to overthrow Awolowo and his group, refused to release Awolowo from jail until the regime itself was overthrown by northern soldiers, who not only released Awolowo but made him the Federal Finance Minister and Deputy Chairman of the Federal Executive Council - the highest position of any civilian in a military government. However, these ironies were either ignored or resolved in favour of the narrative of Fajuyi's heroism.

The fact that Fajuyi was never with Awolowo would ordinarily have robbed him of one of the, if not the, most important element(s) of becoming a good Yoruba, let alone a great Yoruba, in contemporary times. Yet, these paradoxes were erased or resolved by Fajuyi's value to the Afenifere struggle to consolidate its hegemony in Yorubaland and to negotiate inter-ethnic relations, particularly with the other two dominant groups, the Hausa-Fulani and the Igbo. Afenifere compared and contrasted the i 962-6 Yoruba 'feeling of persecution, alienation and suffering' which was not 'universally shared' among the Yoruba, given the Awolowo-Akintola split, with the r993-8 (Abiola's election/annulment) case, during which 'persecution descended on the entire Yoruba nation, even though there was a pocket of minority which benefited from the persecution of its own people'. ${ }^{45}$ In the latter case, the Yoruba 'felt cheated ... felt hunted ... felt the victim of ethnic cleansing' and 'under those circumstances, heroes and heroines flourished, and past heroes loomed into significance'. ${ }^{46}$

History, against this backdrop, becomes an 'immortality ideology'. History (Fajuyi's, as narrated by the Afenifere) was used to monumentalize the past and further establish the "age of the "house", ' of Oduduwa, which is also the House of Awolowo, as a means of 'its [the House's] lien on immortality'. ${ }^{47}$ This process, as Pina-Cabral and de Lima ${ }^{48}$ argue, constitutes one step on the road to what Benedict Anderson ${ }^{49}$ noted as a particular feature of nationalism: 'the submersion of individual mortalities in a collective,

\footnotetext{
42 Ibid. $\quad 43$ Ibid.

45 Ibid. I9.

44 Akinyemi, 'The Afenifere connection', i 9. 46 Ibid.
}

47 João de Pina-Cabral, 'How do the Macanese achieve collective action ?' in João de Pina-Cabral and Antónia Pedroso de Lima (eds.), Elites: Choice, Leadership and Succession (Oxford, 2000), 234. $\quad{ }^{4}$ Pina-Cabral and Pedroso de Lima (eds.), Elites.

49 Benedict Anderson, Imagined Communities (London, I983), I 8. 
permanent, and ageless resurrection of the body politic'. The process of monumentalizing the past through the dead is also a way of announcing, affirming and confirming the authority and status of particular elites. For Shore such instances of the celebration of the dead as that of Fajuyi become 'fundamental (albeit contested) resources for both established and emerging national elites', given that 'they actively construct those histories by which people come to identify themselves' ${ }^{\mathbf{5 0}}$

\section{COMMEMORATING HEROISM}

The inaugural Fajuyi memorial events were held in $200 \mathrm{I}$. They included a lecture, seminars, visits to his family and the publication of an edited volume, The Road to Lalupon: Tribute to Gallantry. On Monday 30 July $200 \mathrm{I}$ in Ibadan, important Yoruba and Igbo dignitaries gathered at the Cultural Centre for the $35^{\text {th }}$ anniversary of Fajuyi's death and the launching of the book in his honour. Seven governors from the Yoruba West and the Igbo East were also present at the occasion, where they eulogized Fajuyi as a 'selfless, detribalised and loyal military officer' who made the ultimate sacrifice. Senator Abraham Adesanya, the Afenifere leader, stated in his speech that:

the various nationalities in Nigeria could pick a lesson or two from the selflessness of heroes like Fajuyi by putting the common good of all above narrow, parochial and selfish interests. The bond between Fajuyi and Ironsi has shown and taught us that no matter our cultural differences, we can establish and nurture beneficial, purposeful and lasting union between ourselves and among our peoples. ${ }^{51}$

The event also included a dramatized presentation of Fajuyi's last hours on earth with Ironsi, his guest, during which Fajuyi's widow, Eunice, wept. Old memories were replayed as the two women widowed by the I 966 assassinations met after a long time. Mrs. Eunice Fajuyi and Mrs. Victoria Aguiyi-Ironsi captured everyone's attention as they walked towards each other and hugged each other for about five minutes as the crowd 'roared in ecstasy and appreciation'. Many rose to their feet in ovation while some in the audience had misty eyes. It was a symbolic moment in the attempt to make the Igbo and the Yoruba 'hug' one another politically. Mrs. Victoria Aguiyi-Ironsi was presented with a posthumous plaque in remembrance of her husband by the Afenifere. She was overwhelmed with joy as she took the prize, stating that: "I am very happy and appreciative of what is happening here today. This shows that my husband and his sacrifice for this nation have not been forgotten and I thank the Yoruba for honouring my late husband' ${ }^{52}$

For Igbo leaders, though the recognition and award to Ironsi were significant in themselves, they were also reciprocal gestures. The Igbo had, on 12 May 200 I in Enugu, under the auspices of the Igbo National Council, organized a reception for worthy Igbo sons and daughters as well as friends

50 Chris Shore, 'Introduction: towards an anthropology of elites', in Chris Shore and Stephen Nugent (eds.), Elite Cultures: Anthropological Perspectives (London, 2002), I 3.

51 Chuks Ugwoke, 'Aguiyi-Ironsi/Fajuyi: old memories linger 35 years after', Vanguard (4 Aug. 200I). Emphasis added.

${ }^{52}$ Ibid. 
of Ndigbo (the Igbo) where Fajuyi was honoured as ezigbo enyi Ndigbo (worthy friend of the Igbo people). At the event, Rear Admiral Ndubuisi Kanu told Lt-Col. Fajuyi's son, Adedayo Fajuyi:

Your father represents the epitome of sacrifice to a true friend. Our appreciation of your father's selflessness is not measured by the prize you receive today. It is not measured by the great number that you find here. It must, instead, be appreciated that this honour being bestowed on your late father is an expression of the Igbo gratitude, the respect and the oneness which must always exist between our people and your family. It is the spirit that must count. For coming to Enugu in grand style, be rest assured [sic] that part of Igboland is your home and [we] do extend [the] same position, [the] same appreciation to other members of Lt-Col. Fajuyi's family. ${ }^{53}$

While Kanu saw the link as basically between the Igbo and Fajuyi's family and not the Yoruba in general, Dr. Chukwuemeka Ezeife, the former Anambra state governor, as a politician who had related more with the Afenifere politicians than Kanu, when he presented the plaque to Adedayo Fajuyi stated the significance as a direct link between the Igbo and the Yoruba. 'This event', said Ezeife:

is historic in many regards. But more importantly, it symbolises true inter-ethnic solidarity. It is the essence of the handshake across the Niger that we have been clamouring for. Your father was and remains an exceptional patriot, a genuine friend of Igbos. This bond will outlive all of us here. It is everlasting and we urge you to take the message home to your family, your state and the entire Yoruba race that our people will never forget what your father did for our son in those trying moments. ${ }^{54}$

In his reaction, Adedayo Fajuyi said the award brought back some old memories: 'I feel fulfilled by this award that will occupy a special place in our home and in our hearts. The Igbos and Yorubas have a lot in common. So, we must always cooperate and collaborate. As for this great honour, we (Yorubas) will reciprocate'. ${ }^{55}$

DEFYING DEATH: THE ROAD TO LALUPON

\section{Commemorations are to histories what funeral eulogies are to obituaries Michael Saler ${ }^{56}$}

Like Zapata in Mexico, ${ }^{57}$ the circumstances of Fajuyi's death are of tremendous significance for the process through which he has been mythified. Lalupon, the sleepy rural community on the outskirts of Ibadan where

${ }^{53}$ Ibid. Emphasis added. $\quad{ }^{54}$ Ibid. Emphasis added. $\quad{ }^{55}$ Ibid. Emphasis added.

56 Michael Saler, 'Hearing voices of the past: comments on Toews and Zolberg', Theory and Society, 27 ( 1998), 595.

57 Samuel Brunk, 'Remembering Emiliano Zapata: three moments in the posthumous career of the martyr of Chinameca', Hispanic American Historical Review, 78 (Aug. I 998), 457-90. 
Lt-Col. Fajuyi and General Ironsi were killed after being abducted by northern soldiers from Government House, Agodi, Ibadan, was turned by those celebrating Fajuyi's memory into 'a metaphor for Courage, Gallantry and Loyalty'. ${ }^{58}$ Fajuyi and his guest, Ironsi, were reportedly taken as far as Lalupon, a distance of about 12 kilometres from Agodi, 'not because the abductors so decided, but because all efforts to persuade Adekunle Fajuyi to get off the Land-rover and leave Aguiyi Ironsi, the main target of the abductors, to his mortal fate were unheeded by the host and Military Governor of the Western Region'. ${ }^{\mathbf{9}}$

Some of the major accounts of what happened on the morning of 29 July I 966 were given by D. J. M. Muffet ${ }^{60}$ and Fajuyi's brother who was present at Government House. Relying on an unidentified informant, Muffet records that Ironsi and Fajuyi were met on the staircase by the then Major Theophilus Danjuma and Lt. Walbe ${ }^{61}$ Fajuyi's brother also recounted, in a television interview, how his brother made a 'frantic plea' and 'furiously insisted' that he would not be separated from his guest, Ironsi. ${ }^{62} \mathrm{Un}$ identified informants claimed that Fajuyi insisted on being killed first. ${ }^{63}$ Muffet concludes that 'The death of Colonel Fajuyi was universally and genuinely mourned throughout Nigeria ... it occurred under circumstances of extreme gallantry' ${ }^{64}$

However, at least one scholar has attempted to contradict the narratives of Fajuyi's heroism. Isiwa Elaigwu dismisses the narratives of 'gallantry' and 'courage' as fictitious, arguing that 'there was no evidence that Fajuyi was killed because he interceded for his host or that he refused to "abandon his guest”, as reported by some publications'. Elaigwu argues that, '[Fajuyi] was reported to have been scared, and had been one of those very much suspected by Northern soldiers. He was one of those marked for elimination ${ }^{, 65}$ on account of his suspected involvement in the plotting of I 5 January i 966 . One of the abductors, Lt. Walbe, reportedly told Elaigwu that it was a lie that Fajuyi chose to die along with Ironsi. ${ }^{66}$

Indeed, in a sense, Elaigwu's claim is plausible, if only at the level of perception. One of the January coup plotters, Major Ademoyega, although refuting Fajuyi's participation in the coup, stated that Fajuyi 'could have been immensely useful to us if he was around' $:{ }^{67}$

As our preparations warmed up, it was no longer possible to make contact with him and so he did not take part. All the same, when he later joined Ironsi's military Government as the Governor of the Western Region, he remained the one unwavering spokesman for the coup and for the revolutionary officers. His singular stand became so well known that we, in detention, knew it when Hassan [Katsina, the Fulani Military Governor of the Northern Region] reportedly turned round

58 Akinyemi Onigbinde, 'Introduction: Keeping Faith with Destiny', in Onigbinde (ed.), The Road to Lalupon, I. 59 Ibid.

60 D. J. M. Muffett, Let Truth Be Told: The Coups d'Etats of I966 (Zaria, I982).

61 Ibid. I 108.

62 Babatunde Oduntan, 'A combatant in government', in Onigbinde (ed.), The Road to Lalupon, 25. 63 'Preface', in Onigbinde (ed.), The Road to Lalupon, xxii.

64 Muffet, Let the Truth Be Told, I03. $\quad{ }^{65}$ Elaigwu, Gowon, 65, 73.

66 Ibid. 72. $\quad{ }^{67}$ Ademoyega, Why We Struck, I 04. 
and dubbed Fajuyi an 'Action Grouper', ${ }^{68}$ thus earmarking him for elimination, come their July 29, I 966 , counter-coup. ${ }^{69}$

For another ranking soldier who has chronicled the history of that era, Major General James Oluleye, Ironsi and Fajuyi paid 'the supreme sacrifice willy-nilly' for 'obvious reasons'. While Ironsi's sins included '[failing] to bring the January i 966 coup plotters to book, his guts at balkanization through the Unification Decree and the subsequent massive promotions of Ibo [Igbo] Army Officers',70 'Fajuyi's own fault was simply that he was found to be anti-north because of his detention of members of the N.N.D.P. who were pro-North' ${ }^{71}$ Oluleye continued:

... The gallant Lt-Col. F. A. Fajuyi ... was magnanimous enough to set free from detention Action Group 'Afenifere' members and they unforgivingly [sic] moved about freely politicking. One could easily come to the conclusion that in a Northern-inspired military uprising, both of them [Ironsi and Fajuyi] had set a death prize on their heads for hurting further the aggrieved North. Therefore, the initial claim by Major T. Y. Danjuma that he assured Lt-Col. Fajuyi of his safety was false. To spare him would amount to a betrayal of the northern cause. ${ }^{72}$

However, Elaigwu was accused by those celebrating Fajuyi's 'sacrifice' of 'being economical with the truth' ${ }^{73}$ because: ( I) Elaigwu was allegedly not faithful to the accounts of the January i 966 coup as rendered by those who took part in it; and (2) the 'national reactions and mourning' that followed the announcement of Fajuyi's assassination did 'not reflect that the North wanted him dead because he had participated in the January coup'. Oduntan argued that Fajuyi's 'death became the unifying dirge that mellowed the anger that many people felt' ${ }^{74}$ Dr. Sam Aluko recorded that 'many northerners could not believe that northern soldiers could be connected with the death of a man so loved'. ${ }^{75}$ Thus, all contrary 'evidence' or statements that contest(ed) Fajuyi's willed sacrifice were dismissed or ignored in the Fajuyi memorial.

Yet, despite the narratives of heroic agency (freewill and choice), the issue of predestination was also central to the Fajuyi memorial. It would appear contradictory on the surface but it was resolved at the level of the political and cultural uses of memory. The commemorative book The Road to Lalupon: Tribute to Gallantry was tagged 'An Afenifere Project', as a way of announcing the group's ownership of the memorial. Contributors to the book paid tributes to Fajuyi by looking at the man and the issues raised by his sacrifice from different perspectives, including those of Nigeria's political history, Yoruba-Igbo relations, the Yoruba concept and practices of honour and courage, and the uses to which the sacrifice could be put in the overall Yoruba political interest. Obituaries written in celebration of Fajuyi when

68 A major crisis in the Western Region 'inherited' by the Fajuyi government was the crisis over the Owo stool. The people of Owo, supporters of Awolowo's AG, had rejected their Oba, Olateru Olagbegi, an Akintola-NNDP sympathizer, who was removed from office and exiled by the AG government. Fajuyi ratified the suspension when he assumed power. Nigerian Tribune, 4 June I966. $\quad{ }_{69}^{6}$ Ademoyega, Why We Struck, I 04.

70 Oluleye, Military Leadership in Nigeria, 34-5. $\quad{ }^{71}$ Ibid. 35. $\quad{ }^{72}$ Ibid.

73 Oduntan, 'A combatant in government', 26. $\quad{ }^{74}$ Ibid. 30. $\quad 75$ Ibid. 
he was killed in 1966 were also added either in the main text of the book or as appendices.

The editor of the Fajuyi volume, Akinyemi Onigbinde, set the premise on which Fajuyi's 'inevitable fate' was predicated. Fajuyi, he argued, 'was destined to be a hero, a revered historic figure, the pride of his proud race and the best of the human specie $[$ sic $]{ }^{\prime}{ }^{76}$ Fajuyi's journey to ancestorhood, Onigbinde states further, 'could not be avoided and nothing was done to avoid its actualization. Appointment with history was dutifully kept, and on schedule'. ${ }^{77}$ His predestination, as the 'modern' Yoruba are disposed to argue in their heavily Judeo-Christian cultural worldview, is compared to the fate of Jesus Christ who 'went to Golgotha as eternal insurance against the iniquities of the Christian world'. ${ }^{78}$ The Yoruba concept of fate/destiny/ predestination (ori/àyànmó/àkúnlèyàn) is therefore deployed in this case as a strong cultural currency within which Fajuyi's sacrifice is to be understood. Yet, despite orí, àyànmó and àkúnlèyàn, a (wo)man who has thus chosen a good ori (lit. 'head', but figuratively 'destiny') - which is also seen as elédá (creator) - in Yoruba cosmology and occult practices, is nonetheless revered and celebrated for doing so, as if $\mathrm{s} / \mathrm{he}$ had a prior agency that (pre-)determined such choice. Ironically, a particular form of primal nominal agency is consequently assumed to be central to the predestination or fate in which (wo)man has no choice. Inevitably, in this cultural understanding of fate, destiny and predestination, anyone who, by any means, avoids his fate or destiny is only destined for a worse fate. In the Fajuyi case, this cultural understanding is explained thus :

Had Fajuyi attempted to save [him]self when the collective honour of a race was in the balance, he and only he would have had to live a wretched life, going about with the accursed stain of Cain to be despised as a symbol of betrayal, an effigy to be avoided wherever he chooses to imprint his blood-smeared feet. At every turn of his misery-filled existence Johnson Thomas Umanakwe Aguiyi Ironsi's shadow would mock him: the ugly face of shame. ${ }^{79}$

The contradictions in the agency-structure, man-society duality evident in the Fajuyi case are further explicated in the fact that, on one hand, refusal to meet his fate would have been read as his personal and exclusive shame, not shared by the 'great culture' to which he belonged; on the other, such refusal is yet read as capable of damaging that 'great culture' and the image of his people, the Yoruba. An example of the first reading is evident in Onigbinde's argument that, had Fajuyi 'chosen to take the line of least resistance, and was dishonourable enough to live, he would have been collectively disowned as a traitor, undeserving of a part from the rich Yoruba legacy of courage and heroism': ${ }^{80}$

Thus, the blame and shame would be his personal liability and his descendants, in perpetuity, would have been saddled with the cross of shame! Yet the 'ifs' of historic re-construction would come handy for his Yoruba kinsmen as we deflect many mockeries from our bereaved Igbo brothers and sisters as they confront us with the evidence of 'our' cowardly betrayal of a friend ... [But] eternal glory to

${ }^{76}$ Onigbinde, 'Introduction', I. Emphasis added. $\quad{ }_{77}^{77}$ Ibid. $\quad{ }^{78}$ Ibid.

79 Ibid. 2. Emphasis added. $\quad{ }^{80}$ Ibid. 3. Emphasis added. 
the carpenter's son [Fajuyi]. Like Jesus of Nazareth, the Ado-Ekiti born Fajuyi did not betray his appointed date with destiny. ${ }^{81}$

On the other hand, it is argued that the choice Fajuyi made was not so much about Fajuyi, but about the culture that produced him:

How could he do otherwise, a true-born Yoruba son, scion of a noble heritage dated far back into antiquity, long before the birth of Christ? Hospitality to strangers, wayfarers seeking soothing balm for tired limbs is one attribute the descendants of Oduduwa [the Yoruba progenitor] have mastered and deployed in large doses, more frequently to personal discomfort and collective tragedy. ${ }^{82}$

The contradictions inherent in these views are ignored. Given that 'the civilization of caring for the stranger, siding with the weak and persecuted, and crying alongside the bereaved has not departed from Yorubaland', ${ }^{83}$ Fajuyi's sacrifice is again narrated as a reflection of an ageless cultural practice. Consequently, if he had failed to offer himself in sacrifice, the Yoruba would also have suffered, in that Fajuyi's 'betrayal' and lack of courage would have been read as emblematic of Yoruba cultural traits. Indeed, the latter accusation was one of the major reasons why the Fajuyi memorial was very important for the Afenifere. As Babatunde Odutan argues:

Arguably, Fajuyi's greatest relevance is his contribution to the image of the Yoruba people. The Yoruba pride has been humbled by the shameful conduct of some. Akintola's conduct in the NNA [Nigerian National Alliance - an alliance of the dominant northern party, NPC, and Akintola's NNDP] was viewed as compromising the race. His preparedness to employ northerners to destroy his own people was reprehensible. As the Army came into the limelight, Brigadier S. Ademulegun further disillusioned the Yoruba by his over ambition. A people who held honour and integrity in high esteem considered his fraternisation with the northern politicians and clandestine political meetings shameful. Fajuyi's performance in government and his heroism became the shining light that epitomised the Yoruba creed. $^{84}$

Thus, the ways in which the Afenifere remember the conflicts of ig6os Nigeria between and within the major ethnic groups (the Yoruba and the others), political parties and ethno-regional factions in the Nigerian Army, and specifically Fajuyi's sacrifice of his life, constitute a means of both 'affirming the community at large and asserting its moral character'. ${ }^{85}$ Jill Dubisch $^{86}$ has argued for understanding the difference between Lawrence Taylor's idea of death as an 'opportunity' and death as an occasion for affirming broader communal values. I argue that this case contests such dichotomy. The death of Fajuyi was an 'opportunity' for the collective that represented itself in him as much as it constituted an occasion for the

81 Ibid

82 Ibid. 5. Emphasis added.

83 Ibid. 6.

${ }^{84}$ Oduntan, 'A combatant in government', $3 \mathrm{I}-2$. Emphasis added.

${ }^{85}$ Nelson, 'Social memory as ritual practice', 443.

${ }^{86}$ Jill Dubisch, 'Death and social change in Greece', Anthropological Quarterly, 62 (Oct. I989), I 89 . 
affirmation of broader communal values evident in the master narratives of Yoruba honour, courage and gallantry that were deployed by the Afenifere.

\section{DEMOCRATIC POLITICS AND THE SOCIAL CONSTRUCTION}

OF HEROIS M

To commemorate, argue Robert Jay Lifton and Greg Mitchell, ${ }^{87}$ is "to combine memory and ceremony, to remind or be mindful - to witness again'. Memory constitutes the key material for commemoration. However, recollection of the past is an active, constructive process, which is beyond simply retrieving information. ${ }^{88}$ To remember, therefore, 'is to place a part of the past in the service of conceptions and needs of the present' ${ }^{89}$ While sociologists, led by Maurice Halbwachs, have stimulated our interest in the collective representation of the past, historians have tried to show how society's conceptions of great men change from one generation to the next. ${ }^{90}$

It is suggested here, against the backdrop of the Fajuyi memorial, that, for the Yoruba, heroism is constructed as much from the singular acts of individuals (in this case, Fajuyi) as from the sociocultural and political material that history furnishes the people. Therefore, even the factors that were capable of robbing Fajuyi of the status of hero, within the historical trajectory, were overtaken by other key factors, past and present, that were critical to the remaking of the Yoruba in the twenty-first century and in their struggle for the negotiation of power both within Yorubaland and in the larger Nigerian polity. For the Afenifere, and, perhaps, the Yoruba at large, given their struggle against military rule-during which many Yoruba leaders were either 'humiliated', harassed, jailed, exiled or/and assassinated - Fajuyi became 'the only hero the Nigerian Army had ever produced' , one whom the Yoruba had 'unpardonably' failed to honour due to oversight, but whom Nigeria had failed to honour due to the fact that 'those who murdered him were still in power'. ${ }^{92}$

With the return of democratic politics in I999, the Fajuyi memorial became part of the elaborate efforts by Afenifere to re-energize the 'bruised' Yoruba nation. The singular hope for a Yoruba presidency, Abiola, had died in July r 998 , shortly after the death of his jailer and 'Yoruba tormentor', General Sani Abacha. Even though General Olusegun Obasanjo, a Yoruba, had become the President in May r 999 as part of the efforts to appease the Yoruba over their alleged ordeal under the military and the death of Abiola, the Yoruba in general regarded Obasanjo as the choice of the 'Hausa-Fulani oligarchy' and an 'outsider' in Yorubaland - one who hated Awolowo, the Yoruba avatar. ${ }^{93}$ Despite Obasanjo's presidency therefore, the Yoruba

${ }^{87}$ Robert Jay Lifton and Greg Mitchell, Hiroshima in America : Fifty Years of Denial (New York, I995).

${ }^{88}$ Barry Schwaltz, 'The social context of commemoration: a study in collective memory', Social Forces, 6 I (Dec. 1982), 374. $\quad{ }^{89}$ Ibid. $\quad{ }^{90}$ Ibid. 374-5.

${ }_{91}$ Akinyemi, 'The Afenifere connection', i 5. Emphasis added.

${ }_{92}$ Ibid. I6. Emphasis added.

${ }^{93}$ Indeed, Obasanjo was roundly rejected at the polls in all of the six Yoruba states in 1999. But he won in all the other parts of Nigeria. In 200 I he won votes in the six states under a controversial pact with the Afenifere whose party, Alliance for Democracy, did not field a presidential candidate. 
political mainstream, centred around Afenifere, continued to push for a sovereign national conference in which the future of Nigeria would be renegotiated. The memorial of Fajuyi's 'phenomenal sacrifice' could therefore also be regarded as part of the symbolic efforts to strengthen group attachment and cultural-nationalist feelings among the Yoruba, organized around the cultural and political supremacy of Afenifere, and thus to strengthen the group in its efforts to engineer structural changes in the Nigerian federation.

In the Fajuyi volume, the rationale for this is explicated against the background of age-long intra-Yoruba rivalries, 'aggression' of other ethnic groups and the refusal of the Igbo, in particular, to 'appreciate' Fajuyi's sacrifice and loyalty to 'their son', General Ironsi, as a basis for Igbo-Yoruba political alliance. Onigbinde captures these sentiments thus:

[T] he Yoruba have not seen in Fajuyi a rallying figure around whom a social agenda can be built. Rather than becoming a reference point for consensus political programme, which guarantees peaceful co-existence, the descendants of Oduduwa have remained restive and intra-group antagonism is on the rise, even in the face of unprovoked aggression from unfriendly neighbours whose age-long desire to subjugate the Yoruba nation and its people has not diminished in the least. ${ }^{94}$

Segun Gbadegesin ${ }^{95}$ in his foreword to The Road to Lalupon, argues that the two 'noble ideals' for which Fajuyi chose to die - (I) 'to avoid a wrong impression of himself and the Yoruba nation by the Igbo', and (2) 'to serve as the sacrificial lamb and the pillar to build a lasting national edifice upon' - had not come to fruition. This was so because 'the majority of the Igbo still do not have a favourable impression of the Yoruba... And a national edifice... has clearly not been erected on the pillar of Fajuyi's supreme sacrifice'. Onigbinde also notes what appears to be a key rationale for the Fajuyi memorial - that is Igbo-Yoruba rapprochement:

Above all, the Igbo have refused to see in the Yoruba people an appropriate ally to be cultivated and nurtured for mutual benefits in a nation-state that is bent on treating both as second class citizens by an internal colonial class with feudalistic orientation. Rather than latch on Ironsi and Fajuyi's mutual emotional support that saw both to their glorious tragic end, the Igbo have found it convenient to emotionally oppose anything where the interest of the Yoruba is well advertised .... [T] he elite of Igboland are quick to remind their less intellectually endowed and politically uninformed compatriots of the so-called I95 I 'carpet crossing' which 'denied' Zik the premiership of the West in an election that was not even fought on party basis, rendering spurious the claim of an NCNC victory over A.G. ${ }^{96}$

Thus, the Fajuyi memorial is used to reconstruct history and present a Yoruba (Afenifere) version of a historical trajectory that remains contentious, even if critical, to Igbo-Yoruba relations in Nigeria. This history dates back to the I940s and the politics of the anti-colonial Nigerian Youth Movement (NYM). During an important election in the NYM, Awolowo and Azikiwe supported different candidates, which provoked curious allegations of 'tribalism', particularly against the former, even though Azikiwe

94 Onigbinde, 'Introduction', 9.

95 Gbadegesin, 'Foreword', xviii-xix.

96 Onigbinde, 'Introduction', 9-го. 
supported a Yoruba (Samuel Akinsanya) while Awolowo supported an Ijaw (Ernest Ikoli) from the east of Nigeria. This crisis led to the fractionalization of the NYM.

This rivalry continued with the attacks by Azikiwe and his West African Pilot newspaper on the formation of the Yoruba cultural group Egbe Omo Oduduwa in the I940s, and the responses by the members of the Egbe to the attacks. This was carried into the contest over the status of Lagos, then the federal capital, a city which Azikiwe and the Igbo preferred to have separated from the rest of the largely Yoruba Western Region in the I95os. This matter also produced such a serious press war between Azikiwe's West African Pilot and the Daily Service, which was controlled by the Yoruba, that it almost degenerated into an open physical combat between the Igbo and Yoruba in 1950 s Lagos. ${ }^{97}$ The next stage of the rivalry between Awolowo and Azikiwe and the supporters of both men was during the parliamentary elections in I954-5 when Azikiwe sought to be the Premier of the Western (dominantly Yoruba) Region. The details of the elections, in which local (town union) parties aligned with the dominant regional (Yoruba-dominated $\mathrm{AG}$ ) and national (Igbo-led NCNC), are today still being contested by the inheritors of the political mantle of both sides of the political divide. ${ }^{98}$ Despite denials of alliance with the NCNC by some members of the important township parties, the NCNC sympathizers - and the Igbo in general - believe that Awolowo used the 'tribal card' to ensure the 'carpet crossing' of the members of the township parties.

The narratives of Igbo-Yoruba understanding constructed around Fajuyi's sacrifice and loyalty to Ironsi are therefore set in contrast to, if not in cancellation of, these long-drawn bitter rivalries between the two groups. The height of that rivalry was the Nigerian civil war. Again, the Igbo accused the Yoruba of 'betrayal' for not also seceding from Nigeria as Awolowo had 'promised', only for Awolowo to be appointed Federal Finance Minister under the northern-dominated military government that went to war with, and defeated, the secessionist Republic of Biafra. As Obayori captures it:

over thirty years after the civil war, such sentiments continue to colour not only the attitude of the Ibos [Igbo] towards the Yoruba but their ideological/political dispositions. Such were the sentiments and sabotaging outlook of the Ibos during the June I 2 struggle in I993-I998 and in their various political alignments in the Second and the present Republics. ${ }^{99}$

Fajuyi's death and sacrifice are therefore assumed by the Afenifere to be capable of erasing not only the bitter rivalries of the past, but also the 'false' Igbo narratives of a 'Yoruba culture of betrayal and lack of courage'. Every time such narratives are brought up, or when they form the basis of Igbo-Yoruba rivalries, 'which invariably throw one [of the two groups] in the secured camp of the enemy', Onigbinde argues, 'the agony of pain and

97 See Wale Adebanwi, 'The city, hegemony and ethno-spatial politics: the struggle for Lagos in colonial Nigeria', Nationalism and Ethnic Politics, 9 (2004), 25-5 I.

98 See, for instance, Ganiyu O. Dawodu, Awo or Zik: Who Won the I95I Western Nigeria Election? (Ibadan, I 998).

99 Femi Obayori, 'Heroism in broader perspective', in Onigbinde (ed.), The Road to Lalupon, 53 . 
regrets from Fajuyi echo far from his grave. And the man dies a second time'. 100

Also, despite the assumed 'refusal' of the majority of the Igbo to recognize Fajuyi's sacrifice and the continued 'negative' impression of the Yoruba - as 'undependable and traitor[s]' - Gbadegesin argues that:

Adekunle Fajuyi [made] the supreme sacrifice so that the Yoruba can walk the street with their heads raised high. For this, we would be eternally grateful to him, as we continue to raise our heads high as a proud and principled nation, no matter what anybody, nation or race, thinks of us. ${ }^{101}$

Furthermore, Afenifere attempted, through the Fajuyi memorial, to erase the contention over how and why he was killed by imposing its own narrative on the event as history. The group took a source of dispute, disagreement and even disunity and attempted to turn to it into the basis not only of ethno-national glory, but also for cross-ethnic (Igbo-Yoruba) political engagement and harmony. In doing this, the group fished out a specific event from 'a sea of seemingly weed-like, tangled occurrences' 102 and promoted its own interpretation of that event. That interpretation was however coloured by contemporary dynamics in Yoruba relations with the other dominant ethnic-nationalities in Nigeria. Another purpose that can be deduced from the Fajuyi memorial is Afenifere's eagerness to construct, and then appropriate, cultural values and virtues which are supposed to be reflected by the singular act of sacrifice. This is reflected by all the contributors to the volume, who are eager to give the lie to the accusations of Yoruba 'conspiracy' ${ }^{\text {103 }}$ or 'Yoruba inherent treacherous tendencies', ${ }^{104}$ and to pronounce the Yoruba as a people who constantly prove their honour and integrity as omoluwabi. ${ }^{105}$

Despite the history of bitterness and rivalries between the Igbo and Yoruba, the Fajuyi memorial rendered a 'consolation' or a 'new spirit [that] is abroad' making it possible for the 'wall of suspicion [between the two ethnic groups to be] pulled down'. In this context, 'On the grounds where the "Berlin Wall" of division and hatred once intimidatingly stood, the grass of cooperation and mutual respect, for our common destiny, is now sprouting'. ${ }^{106}$ Joe Igbokwe, one of the Igbo social critics and activists who was vocal in support for the validation of the 1993 presidential election won by a Yoruba, Moshood Abiola, emphasizes in the collection of essays that Fajuyi represents a basis for 'mutual respect' and recognition of Igbo-Yoruba 'common destiny':

There are many ... examples of this age-long attempt to foster good relationship between the Igbo and the Yoruba. But the greatest of such attempts was when Lt-Col. Adekunle Fajuyi ... refused that his guest, Major General Aguiyi

\footnotetext{
100 Onigbinde, 'Introduction', I о-I I. 101 Gbadegesin, 'Foreword', xix.

102 Zolberg, 'Contested remembrance', 566.

103 Demola Adegbamigbe, 'The sacrificial lamb', in Onigbinde (ed.), The Road to Lalupon, 47. 104 Obayori, 'Heroism in broader perspective', 53.

${ }^{105}$ Roughly, this word would translate as 'gentleman' in English, but it carries greater cultural codes. Depending on the context in the local language - as in this case - it can also mean the plural, 'gentlemen'. Onigbinde, 'Preface', xxiv.

106 Onigbinde, 'Introduction', in Onigbinde (ed.), The Road to Lalupon, Iо-I I .
} 
Ironsi ... should die alone in his territory. [The] Igbo must as a matter of urgency begin a move to erect a monument for Lt-Col. Fajuyi and Chief Adeniran Ogunsanya in Enugu, the former capital of Eastern Region. It will help the nation ... The duty we owe the late Lt-Col. Fajuyi is to initiate more handshakes ... in the South ... so that the foundation will be so strong that nobody will break it as long as Nigeria exist[s] as a political entity. Yes, a man who laid down his life for the benefits of his friends deserves to be so honoured. ${ }^{107}$

It is interesting to note that, apart from a rash of newspaper articles in early i 967 when Fajuyi's - and Ironsi's - assassinations were formally announced, and the general mourning around the country, particularly in Yorubaland, which led to a few streets being named after him, Fajuyi was not remembered in any organized manner from I 966 until $200 \mathrm{I}$ when the Afenifere organized the memorial. In a country that is suffused with naming of monuments and public institutions - universities, airports, Government Houses-only a few major public institutions were named after Fajuyi outside of his homeground of Ekiti land: that is, a residential hall at the Obafemi Awolowo University in Ile-Ife, and Adekunle Fajuyi Barracks at the Odogbo Military Cantonment in Ibadan. He was indeed 'forgotten' for three decades by the same power elite that was celebrating him in the twenty-first century. Even when its key members held power as governors in the five Yoruba states in the Second Republic (I979-83), no Fajuyi memorial was deemed important. It could not have been a mere oversight. But, at that time, there was no crucial need to remember Fajuyi. Even when he was eventually remembered and recognized in the more elaborate attempts at ensuring a strategic alliance between the Yoruba and Igboagainst the 'Hausa-Fulani oligarchy' - in the politics of the early twentyfirst century, Fajuyi was soon abandoned as an unimportant figure in this task. An indication of this was that, in 2006, the fourth decade of Fajuyi's death, Afenifere, which has since been sundered by the loss of all but one of its gubernatorial candidates in the 2003 elections, did not issue a statement, let alone organize another memorial for the 'soldier [who] gallantly sacrificed himself for the collective honour and integrity of his kinsmen and women'.

I argue that the uses of Fajuyi's death and his 'unique status' in the pantheon of Yoruba heroes were politically functional. The moment of commemoration was one in which his death represented a narrative of collective (ethno-national) glory instrumentalized in the political project of a collective future. The memorial turned the action of a single man into the representation of a collective (ethnic) disposition, and a representation of the positive qualities of his people. 'He [was] an illustrious and worthy example and representative of the Yoruba nation', states Jumoke Anifowose. ${ }^{108}$ This fed into the larger political and cultural uses of heroes in Yoruba politics. Comparatively, the narratives of the three major Yoruba heroes, Awolowo, Abiola and Fajuyi, are similar at the level of men of courage faced with daunting ('reactionary', 'conservative', 'Hausa-Fulani',

${ }^{107}$ Joe Igbokwe, 'A matter of duty', in Onigbinde (ed.) The Road to Lalupon, 98.

108 Jumoke Anifowose, 'The imperative of unity', in Onigbinde (ed.), The Road to Lalupon, 87. 
'northern', 'hegemonic' or 'caliphate') odds and sacrificing themselves, their lives (Fajuyi, Abiola) and/or their freedom (Awolowo, Fajuyi, Abiola) for the collective.

The narratives of Fajuyi's sacrifice further reflect the continued battle for national accommodation and against 'ethno-regional domination and hegemony' between the three major ethnic groups in Nigeria - Hausa-Fulani, Igbo, and Yoruba - as understood by the dominant Yoruba power elite, the Afenifere. Fajuyi's memorial was an opportunity for the Afenifere to recall and re-articulate these long-drawn-out, even historic, battles to remove the road block to 'our destiny as a nation'. ${ }^{109}$ Beyond 'mere theorizing and glorification of the deeds of [their] forebears', the Yoruba are called upon to 'take positive action to change' their reality by making 'the spirit of our forebears come alive in the life of our people'. ${ }^{110}$ As one of the contributors to the volume puts it:

The Sovereign National Conference is therefore necessary not only because of resources control or because we must grab more power from the centre, but, also, because our history, our culture, our mores and more importantly, our heroes and heroines and the pedagogic potentials they enshrine for our youth and posterity stand endangered, so long as we remain enshackled [sic] within Nigeria as constituted ... Rather than turning our heroes into dead, inanimate icons, they must be kept alive as flashing beacons for plotting the ship of the Yoruba nation away from the adversary's camouflaged crags and icebergs ... We must not allow our leaders ... to escape with the notion that it is enough to pay lip service to the heroism of our ancestors. ${ }^{111}$

The strong code of 'following-the-tradition-of-valour' as exemplified by the ancestors is repeated again and again in the Fajuyi memorial book. For instance, it is argued in different ways that Fajuyi could not have taken the option of 'abandoning' his guest by choosing to live because 'indeed his ancestral values forbid it'. Therefore:

Fajuyi [had to do] what a true Balogun [war general] would have done in preference to being captured. He did that which his class of ancestral war leaders would rather do in the face of imminent disgrace and impending accusation of complicity... [He] was, and still [is], the archetypal Yoruba war General faced with a difficult choice between treachery and honour. He chose honour and paid the supreme price. ${ }^{112}$

That Fajuyi died rather young (forty), particularly ahead of his parents, which is taken as a special kind of tragedy in Yorubaland, made him follow an unusual route to ancestorhood. As has been pointed out by those celebrating Fajuyi's sacrifice, he knew not, as in tradition, the cost of adiye irànà, the sacrificial fowl, paid for by the children of a deceased old man, which believers in Yoruba traditional religions use 'to cleanse the path to heaven so that the dead may have easy passage amidst numerous evil spirits that line the route to the abode of Olódumarè [God]'. By becoming the 'sacrificial lamb' himself, Fajuyi became an instant ancestor through the process of his death; 'rather than betray his ancestors and bury the history of

109 Obayori, 'Heroism in broader perspective', $56 . \quad 110$ Ibid.

111 Ibid. 55, 56. 112 Anifowose, 'The imperative of unity', $8_{5}$. 
generations after him in the mud, he surrendered his life as a form of appeasement'. ${ }^{113}$

\section{DEATH, ANCESTORS AND POLITICAL AGENCY}

Across time and culture, death has been a constituent feature of the fabric of life. ${ }^{114}$ The basic task of any social system is to give symbolic order and meaning to man's mortality. ${ }^{115}$ In this context, the traditional religious task of imposing meaning on death has been taken up by new social formations including the state, nations and cultural groups. What emerges from this is the 'political potency of the dead as symbols', as 'the dead continue to have a powerful influence on the political life of the living'. ${ }^{116}$ 'This essay has argued for the capacity of the dead to play a role in modern, democratic politics. It deals with death and heroic history, emphasizing what Jack Goodydescribes as the 'symbolic and ideological halo around the physiological facts of death'. ${ }^{117}$ In the Fajuyi case, death is signified and made significant as - and converted into - a basis of ethno-national unity.

Ali Mazrui has argued that, given the 'abstract' and 'cold' nature of the idea of nation in commanding human allegiance, to give the idea warmth ' it is often necessary to either personify it metaphorically or, more effectively, to give it specific human form in national heroes'. ${ }^{118}$ This, he argues, explains why ancestor worship, which is 'only a special form of the wider phenomenon of hero-worship', is so important among 'tribes' and nations. ${ }^{119}$ Ancestors occupy a central place in African cosmologies and social practices. There is an assumption in the anthropological literature that the idealization of ancestors is independent of their lifetime careers, even if only in principle. ${ }^{120}$ Scholars of ancestor worship argue that, though the ancestor is someone in particular, he does not have to behave as anyone in particular. In this context, inactivity is further assumed to be the most important characteristic of ancestors. ${ }^{121}$ Ancestors therefore exist only in collective (imaginations of) agency. This assumption overlooks specific instances where ancestors are first recognized in terms of their singular agency, which is subsequently collectively appropriated and narrated as over-representing collective agency.

However, while ancestor worship constituted one of the most contentious areas of study among anthropologists working in Africa for many decades, ${ }^{\mathbf{1 2 2}}$

113 Ayo Fadahunsi, 'Akinkanju Omo Oodua', in Onigbinde (ed.), The Road to Lalupon, 44. $\quad 114$ Kearl and Rinaldi, 'The political uses of the dead', 694.

115 Ibid. 696.

117 Jack Goody, 'Death and the interpretation of culture: a bibliographical overview', American Quarterly, 26 ( I 974), 448-55.

118 Mazrui, 'On heroes and uhuru worship', 24. 119 Ibid.

120 C. J. Calhoun, 'The authority of ancestors: a sociological reconsideration of Fortes's Tallensi in response to Fortes's critics', Man, I 5 (June I980), 3 I I .

121 Ibid. 3 I 3.

122 See Igor Kopytoff, 'Ancestors as elders in africa', Africa, 4I (I97 I), I29-42; Igor Kopytoff, 'The authority of ancestors', Man, i6 (Mar. I98I), I35-8; Dean Sheils, 'Towards a unified theory of ancestor worship: a cross-cultural study', Social Forces, 54 (Dec. I 975), 427-40; Calhoun, 'The authority of ancestors'; Roger Keesing, 'Ancestors, sociology and comparative analysis', Man, i 8 (Mar. I983), I85-90; John C. McCall, 
it seems that it no longer holds much fascination in recent years. The academic disinterestedness has been assumed to be a reflection of practical reality. Meyer, for instance, argues that 'ancestors appear to have lost their cultural currency as new forms of social relations emerged in colonial [and obviously, postcolonial] contexts'. ${ }^{123}$ But McCall argues correctly that the disappearance of ancestors from Africanist literature since the r 970 ' owe[s] more to a shift in anthropological paradigms than to changes in African practices on the ground'. ${ }^{\mathbf{2 4}}$ Indeed, 'secular' forms of ancestor worship, which continues to be prevalent in the continent, seem to escape the attention of anthropologists, in particular, and other social scientists in general. Here, I have used recent history to call attention to the continued fascination with ancestors in contemporary Africa.

The capacity of the late Fajuyi to unify is played out in the context of Yoruba belief in the efficacy of the dead, as evident in their worship of the dead who became ancestors, gods or oracles. The Yoruba talk about the spirit of the dead haunting specific people. They believe that the dead can harm as well as enhance-so, they propitiate the spirit of the dead. Yet, there is a certain freedom enjoyed by devotees of the dead-gods (orisas) or ancestors - in Yorubaland. In traditional Yoruba thought and practice, an 'orisa's power and splendour depend on ... having numerous attentive ... devotees to glorify its name. An orisa without devotees fades into insignificance as far as the human community is concerned'. ${ }^{125}$ 'This is why the Yoruba say 'orisa, b'ole gbemi, fi mi s'ile b'ose bami' (lit.: 'god, if you cannot enhance me, let me remain in the condition in which you found me'). People change the god they worship at will, if they think it has not provided their needs. While Karen Barber argues that the Yoruba orisa 'seems in some ways very much like a magnified image of the Big Man', Andrew Apter ${ }^{126}$ pushes that further by recognizing that the orisa is a 'cluster concept' which includes ancestor, Big Man (cultural-hero) and nature-spirit all rolled into one. In a sense therefore, just as there is a symbiotic relationship between the Big Man and his clients, there is a symbiotic relationship between the orisa and the devotees; thus, 'the supporter (or devotee) builds up the reputation of his protector (the Big Man or the orisa) and then benefits from it'. ${ }^{127}$ In fact, Barber notes correctly that mutual dependence between the orisa and devotee goes much deeper. She captures it as a 'collusion'. ${ }^{28}$ The idioms provided by Yoruba cultural thought and practices are used by social actors in understanding contemporary politics, locating political practices, interpreting experience and justifying actions.

\footnotetext{
'Rethinking ancestors in Africa', Africa: Fournal of the International African Institute, 65 (I 995), 256-70.

${ }^{123}$ Cited in Jennifer Cole and Karen Middleton, 'Rethinking ancestors and colonial power in Madagascar', Africa, 7 I (200I), 2.

124 McCall, 'Rethinking ancestors in Africa'.

${ }^{125}$ Karin Barber, 'How man makes god in west Africa: Yoruba attitude towards the orisa', Africa, 5 I (1981), 725.

${ }^{126}$ Andrew Apter, Black Critics and Kings: The Hermeneutics of Power in Yoruba Society (Chicago, 1992), I 52-4. $\quad{ }^{127}$ Ibid. 736. $\quad{ }^{128}$ Ibid. 737-8.
} 
The Fajuyi memorial can be regarded as a secular ${ }^{129}$ form of ancestor worship in which the worth of a recent ancestor was demonstrated. ${ }^{130}$ The 'heroizing narratives', ${ }^{131}$ in which Fajuyi's death was couched, I have argued, are useful in the imagined past, present and future political encounters of the Yoruba and the other ethnic nationalities in Nigeria. All the assumed positive qualities and collective virtues of the Yoruba nation are narrated through commemoration and historically projected as embodied in Fajuyi; thus, the 'Heroic I' becomes a representation of the 'Heroic We', given that, as Calhoun correctly argues, ${ }^{132}$ the fact that 'ancestors are dead makes it much easier to idealise them, to have them represent lineage values as opposed to personal interests or idiosyncrasies of judgement'.

129 By 'secular' here, I mean non-religious.

130 Reed L. Wadley, 'Disrespecting the dead and the living: Iban ancestor worship and the violation of mourning taboos', Fournal of the Royal Anthropological Institute, 5 (Dec. I 999), 595 .

${ }_{131}$ L. H. Malkki, Purity and Exile: Violence, Memory and National Cosmology among Hutu Refugees in Tanzania (Chicago, I 995).

132 Calhoun, 'The authority of ancestors', 3 I 3. 